Research Article

\title{
The Impact of Corporate Social Responsibility on Corporate Financial Perfomance in Tanganyika Wilderness Camps Limited in Arusha Region, Tanzania
}

\author{
Dr. David A. O. Aunga ${ }^{1}$, Mr. Michael Nathan ${ }^{2}$ \\ ${ }^{1}$ Lecturer in Accounting and Taxation, Faculty of Business Administration of, The University of Arusha \\ ${ }^{2}$ Accounts Receivable Controller,Tanganyika Wilderness Camps Ltd.
}

\begin{abstract}
The study was intended to determine the effect of corporate social responsibility on financial performance. Financial performance was measured by use of ROA and ROE. Data was obtained from financial statements, websites, publications and annual reports. Financial performance was the dependent variable while corporate social responsibility was the independent variable. The study revealed that there is a positive relationship between CSR and CFP at TWC. Based on findings, it is concluded that CSR is important for improving financial performance of firm. Companies should partner with non-profits and government agencies to solve social, economic, and psychological problems in society. Companies should involve in wellbeing programs. Research results are supportive of the view that responsible firm behaviour may not only keep employees motivated and help to increase their loyalty but also become a cause to improve the financial performance of firm.
\end{abstract}

Key Words: Corporate social responsibility; Employee Relation; Stakeholder Relations; Corporate Financial Performance; Profitability Ratios; Return on Asset; Return on Equity;

\section{INTRODUCTION}

Understanding the impact of corporate social responsibility (CSR) on corporate financial performance (CFP) is very vital for any business. Social Responsibility has gained considerable ground and it is now common for corporations to get involved in activities resembling those carried out in the name of development \& assistance. Organizations which eventually practice this approach are looking for answers for questions such as does Corporate Social Responsibility really payoff or have any impact on business success financially? Generally, CSR is explained as corporate engagement in socially responsible behaviour in response to societal demands (Idowu and Louche, 2011). Moreover, CSR is a construct that encompasses the economic, legal, ethical, and discretionary expectations that society has of organizations at a given point in time (Carroll, 2007).

CSR is about how firms manage business operations to produce positive impact on society. Consequently, firms need to account for the quality of their management (both in terms of people and process) and the nature of and quantity of their impact on society in various areas (Baker, 2004). An organization needs to define its role within the society and implement the necessary ethical, responsible, legal, and social standards (Lindgreen et al., 2008; Lichtenstein et al., 2004). Therefore, an organization has an obligation to consider the interests of customers, employees, shareholders, communities and ecological considerations in all aspects of their operations (Gokulsing, 2011; Gössling and Vocht, 2007).
Debate is growing about the convenience for the companies of carrying out Corporate Social Responsibility practices, evidence by (Hayek, 1969), (Dressel, 2003), (Freeman, 1984), (Friedman, 1970) among others, and especially the lack of agreement on the relationship between Corporate Social Responsibility (CSR) actions and Financial Performance (FP) (Davidson and Worrell, 1990), (Ruf, 2001). Generally, CSR is explained as corporate engagement in socially responsible behaviours in response to societal demands (Idowu and Louche, 2010). Moreover, CSR is a construct that encompasses the economic, legal, ethical, and discretionary expectations that society has of organizations at a given point in time (Carroll, 2007).

Crisostomo et al. (2011), conducted an investigation on the relationship between CSR and corporate performance by using both accounting based performance measures (e.g. ROA, ROE, and ROS) in Brazil. Results showed that there is a negative effect of CSR on firm value in Brazil. It is strongly affected by employees and environmental action. Employees (internal social action) have a negative effect on financial performance, while external social action and environmental action have neutral effect on financial performance. According to (Yang, Lin, and Chang, 2010), in their study to explain the relationship corporate social responsibility and firm's financial performance and also found to know whether corporate social responsibility has any impact on corporate financial performance or not in Pakistan. CSR has positive impact on CFP, while the impact of CFP on CSP is uncertain. This study 
used ROA and ROE measure CFP.

Waddock and Graves (1997) studied the linkage between corporate social performance (CSP) and financial performance; they hypothesized a positive relationship between CSR and financial performance using CSP as a measure of CSR and return on investment (ROI), return on assets (ROA) and return on equity (ROE) as measures of profitability or the firm's financial performance.

However, Baskin (2006) found that South Africa has not only a significant Socially Responsible Investment (SRI) Index among emerging economies but also the most developed CSR outlook in Africa and the Middle East as a result of the domestic pressures of CSR and the influence of corporate governance (Baskin, 2006).

According to Sarwar Uddin Ahmed et al, (2012), the research is done to investigate the linkage between CSR and CFP on the banking sector. Corporate social responsibilities CSR has a lot of outcomes towards firm financial performance. Therefore, it is very important for firms to understand the role corporate social responsibilities CSR on Firms financial performance. In this study, researcher proposes to examine the impacts of corporate social responsibility in Bangladesh by using questionnaires survey. CSR is determined from the dimensions of values and transparency, workplace, corporate governance practices, environment and community, while CFP is determined using ROA, earnings per share and price earnings ratio. This study showed that it needs more detailed follow-up studies in order to monitor the linkage between CSR and financial performance.

Okiro, Omoro and Kinyua (2013) tested the relationship between investment in CSR and sustained growth of commercial banks in Nairobi County. The findings revealed an increasing positive attitude towards CSR in terms of investment. There was a general agreement that CSR was essential for the success of the firm. (Okoth, 2012) found out that CSR was good for the financial performance of large and medium size banks and had no effect on the ROA of small banks in Kenya.

Corporate social responsibilities CSR has a lot of outcomes towards firm financial performance. Therefore, it is very important for firms to understand the role of corporate social responsibilities CSR on Firms financial performance. In this study, researcher examined the impacts of corporate social responsibility on corporate financial performance at Tanganyika Wilderness Camps Limited in Arusha region

\subsection{Research Questions}

i. What are the types of corporate social responsibility (CSR) practices towards corporate financial performance in TWC?

ii. What is the level of relationship between Cooperate social responsibility (CSR) and corporate financial performance (CSP) in TWC? iii. What are the impacts of corporate social responsibility practises on financial performance in TWC?

\section{REVIEW OF RELATED LITERATURE}

A lot of studies have been done in the area of CSR both globally. The findings are mixed and inconclusive. (Abiodun, 2012) carried out a study to determine the effect of CSR on firms ${ }^{\text {ee }}$ profitability in Nigeria. In this study, secondary data was collected from ten profitable firms randomly selected on the Nigeria Stock Exchange. Using regression analysis, the study found a negative relationship between firms ${ }^{\text {ee }}$ CSR performance measure with profit after tax and investment in CSR.

According to Margolis and Walsh (2002), one hundred twenty-two published studies between 1971 and 2001 empirically examined the relationship between corporate social responsibility and financial performance. The first study was published by Narver in 1971. Researchers (Sandra Waddock and Samuel Graves 1997) of Boston College made a study on two aspects of the topic: (1) whether there is a positive or negative relationship between corporate social responsibility and financial performance of a company or if no relationship exists at all between them. (2) If the exists a relationship then, whether the financial performance was due to the previous practises of CSR or if CSR was a succession as a result of high financial performance.

Waddock and Graves (1997) utilized the data collected from and independent research organization. The data was collected of all the companies in the S \& P 500. The data was calculated for each company's CSR performance based on a rating scale that integrated eight important attributes of CSR namely environment performance, staff diversity, staff relations, community relations, product features, military contracts and involvement in South Africa. The above attributes were then ranked according to their relative significance. This scaling method involving eight aspects of community welfare solved the problem of measuring the largely diverse CSR activities, which was faced by previous researchers.

Waddock and Graves studied the links between CSR and CFP of 469 firms during the year 1989 through 1990. The firms were from different sectors of business industries including hospitals, aerospace, mining, publishing and utilities. The study made use of different figures of finance like return on assets (ROA), return on sales (ROS) and return on equity (ROE). The analyzing of data from two consecutive years meant that the duo researchers could test the slack resources theory, which tests if better CFP leads to a better CSR in the consecutive year. The theory which finds out if a good CSR leads to improved financial performance, was called the good management theory. This theory was studied with CSR data in the year 1990 and compared with the CFP figures of 1991, therefore with a time lag of one year.

Various other studies were conducted to evaluate the relationship between corporate responsibility and financial performance. They produced mixed results: (Konar and 


\section{Dr. David A. O. Aunga et al / The Impact of Corporate Social Responsibility on Corporate Financial Perfomance in Tanganyika Wilderness Camps Limited in Arusha Region, Tanzania}

Cohen, 2001) in their study on the relationship between corporate social responsibility (CSR) practice and firm financial performance, this research founded a positive correlation exists between a firm's environmental performance and its intangible asset value.

Jaggie and Freedman (1992) negative relationship This research studied specifically 13 firms involved in the pulp and paper manufacturing for the year 1978. An emission index used to measure the environmental performances of the companies was used. The firms that had the highest emission output were categorized with an index of 100 and the rest of the firms were adjusted regarding to that. Then the net income, cash flow/equity ratio and ROA indices were combined, with each of them having equal weights, with these pollutant indices. The outcome of the study showed a negative association between environmental and financial performance.

Lorraine (2009) studied the relationship between CSR and financial performance using structural equation modelling. His findings were that; all respondents had knowledge of the term CSR, however, not all respondents used the term CSR and others such as "corporate citizenship" and "corporate responsibility and sustainability" were offered as alternatives. It was noted that some SMEs felt the word "Corporate" alienates small firms and implies CSR is more complicated than it is in reality, while some large firm respondents felt the word "Social" confined their CSR activities to those of a social nature. With regard to the management of CSR, all large firms interviewed had devoted persons or departments to CSR, while no SME had a separate CSR department, the management of CSR was assumed by senior management, in most cases the CEO. It was also noted that CSR was more formal, strategic and integrated into all aspects of the business in large firms than in SMEs. While definitions of CSR differed from firm to firm, (Lorraine, 2009) realized that a commonality among them was that CSR was generally defined by reference to stakeholder theory in that a firm was socially responsible if it took into account the interests and needs of its group of stakeholders. CSR activities are positively correlated with firm size.

Margolis, Elfenbein and Walsh (2007), in their study to analyze the effect of CSR-related shareholder proposals that pass or fail by a small margin of votes, while carrying out a meta-analysis of the results from 167 studies, found that $27 \%$ of the analyses showed a positive relationship, $58 \%$ showed a non-significant relationship, and $2 \%$ showed a negative relationship between CSR and CFP. Building up on the view of CSR as a resource, the CSR-CFP relationship is influenced by both the company's social performance and institutional norms of CSR in the firm's industry. In support of the view that CSR is a valuable resource for firms, they found that CSR-related shareholder proposals that were adopted led to superior financial performance as compared to firms whose CSR-related shareholder proposals were rejected. The researchers realized that adopting the proposal led to an increase in ROA by $0.7 \%$ to $0.8 \%$, and an increase in NPM by
$1.1 \%$ to $1.2 \%$ in the two fiscal years following the adoption of CSR. They also found that the stock market reacted positively to the passage of close-call CSR proposals in the two-day event window following the announcement of the vote. A CSR proposal that passed yielded a positive cumulative abnormal return of $1.9 \%$ compared to a proposal that failed.

A study by Gathungu and Ratemo (2013) revealed that disclosure of the CSR activities by organizations was used as a measurement tool of performance in the sense that the investment in CSR activities was an indication of the level of resources available and more especially the value that the organization had ascribed to the beneficiaries of the programs. Though CSR was considered part of the operations of an organization, its impact on the organization's financial performance was slightly different from that of other functions such as production, finance, selling and distribution. Therefore, if it would not be possible to establish a clear relationship between CSR and corporate performance, the social and environmental responsibility of the organization was likely to remain at the level of empty mission statements and isolated add-on activities which in turn would affect the performance of the organization. The study revealed that CSR practices were aligned with the strategic intent and that generally the CSR programs met the expectations of employees, investors and local community.

\section{RESEARCH METHODOLOGY}

\section{Research Design}

A research design constitutes decisions taken by a researcher regarding what, where, by how much and by what means concerning an enquiry or a research study (Kothari, 2007). The selection of a research design in social sciences is dependent on the researcher's determination of the approach he or she intends to use to answer their research questions (Sekaran, 2003; Saunders et al. 2009). The research design for this study was descriptive design. A descriptive survey describes and interprets "what is" and is concerned with conditions or relationships that exist; practices that prevail; beliefs, point of view, or attitudes that are held; processes that are going on; effects that are being felt; or trends that are developing (Manoharan, 2009).

\section{Data collection methods}

These are the methods which were used in collecting data in this research; there are several research instruments that researchers utilized in conducting research. In this research, the researcher used questionnaire. In this research the questionnaires were carefully designed instrument for collecting data in accordance with the specifications of the research questions (as per appendix I attached).A questionnaire ensures standardization and comparability of the data across interviewers, increases speed and accuracy of recording and facilitates data processing ((Malhotra, 2005)).The questionnaire was divided into two parts whereby the first part was for respondent's biography, part two was for examining the effects of CSR on CFP at Tanganyika 
Wilderness Camp (TWC) for objective one and two whereby objective three relied on financial reports and statements from TWC.

\section{DATA ANALYSIS, INTERPRETATION AND DISCUSSIONS}

1. Types of Cooperate social responsibility (CSR) activities towards corporate financial performance (CSP) in TWC.

The study revealed that the company TWC practices the corporate social responsibilities at large. $44.7 \%$ strongly agreed, $25.5 \%$ agreed, $12.4 \%$ disagreed and $10.7 \%$ strongly disagreed to types of Cooperate social responsibility (CSR) activities towards corporate financial performance (CSP) in TWC. From the data also obtained from the study, it was found that $50(52.1 \%)$ of the respondents strongly agreed that environmental care is one of the type of CSR activity found at TWC whereby $25(26 \%)$ agreed, $12(12.5 \%)$ disagreed while the remaining $9(9.4 \%)$ strongly disagreed that environmental care is not one of the type of CSR activity found at TWC. 64 (66.7\%) of the respondents strongly agreed that Education is one of the type of CSR activity found at TWC whereby $32(33.3 \%)$ whilst $0(0 \%)$ disagreed and strongly disagreed respectively.

Moreover, the study data revealed that 37 (38.5\%) of the respondents strongly agreed that health care is also one of the CSR activity practiced by the organization, 25(26\%) agreed, $18(18.8 \%)$ disagreed while the remaining 16 (16.7\%) strongly disagreed to that concept. data obtained from the study in regarding to if Peripheral Development is one of the activities also practiced by TWC. The study revealed that $47(49 \%)$ strongly agreed, $29(30.1 \%)$ agreed whilst $2(2.1 \%)$ disagreed and the remaining $18(18.75 \%)$ strongly disagreed that Peripheral Development is not one of the activity also practiced by TWC.

The study data also revealed that 13 (13.5\%) of the respondents strongly agreed on housing as one of the organizations CSR activity, 12(12.5\%) agreed, 37(38.5\%) disagreed while the remaining $34(35.5 \%)$ strongly disagreed and data obtained from the study in regarding to if Tanganyika Wilderness Camps do village adoption as their CSR activity. The study revealed that 56(58.3\%) strongly agreed, 33(34.4\%) agreed whilst $1(1 \%)$ were those who disagreed and the remaining 6(6.3) of the respondents strongly disagreed.

In addition, the study data revealed that $66(68.8 \%)$ of the respondents strongly agreed that community involvement is one of the type of CSR activity found at TWC whereby $25(26 \%)$ agreed whilst $3(3.1 \%)$ disagreed and $2(2.1 \%)$ strongly disagreed. This proves vividly that TWC practice community involvement as one of the CSR activity a lot to ensure community development as well as recognition in the surrounding community. The study data also revealed that 61 $(63.5 \%)$ of the respondents strongly agreed that TWC practice Employment \& Employability as one of their CSR activities, $22(22.9 \%)$ agreed while $11(11.5 \%)$ disagreed and the remaining 2(2.1\%) strongly disagreed.

Finally, the study data revealed that rural sports is practiced only by $10(10.4 \%)$ who were those who strongly agree, 18 (18.8\%) agreed, 25(26\%) disagreed while the remaining 43 (44.8\%) strongly disagreed. According to the frequency and percentage presented in this section, this shows vividly that the organization doesn't support rural support as one of their CSR activity where also the study data revealed that 68 (70.8\%) of the respondents strongly agreed that welfare is also one of the CSR activity practiced by the organization, $22(22.9 \%)$ agreed, $1(1 \%)$ disagreed while the remaining 5 (5.3\%) strongly disagreed to that concept. This also proves that welfare is really a CSR activity practiced in this organization.

Table 4.3: Types of Cooperate social responsibility descriptive statistic presentation

\begin{tabular}{|l|l|l|c|}
\hline Types of CSR & N & Mean & $\begin{array}{c}\text { Std. } \\
\text { Deviation }\end{array}$ \\
\hline $\begin{array}{l}\text { Environmental care as type of } \\
\text { CSR Activity found at TWC }\end{array}$ & 96 & 3.21 & .994 \\
\hline $\begin{array}{l}\text { Education as type of CSR } \\
\text { Activity found at TWC }\end{array}$ & 96 & 3.67 & .474 \\
\hline $\begin{array}{l}\text { Health Care as type of CSR } \\
\text { Activity found at TWC }\end{array}$ & 96 & 2.86 & 1.111 \\
\hline $\begin{array}{l}\text { Peripheral Development as } \\
\text { type of CSR Activity found at } \\
\text { TWC }\end{array}$ & 96 & 3.09 & 1.125 \\
\hline $\begin{array}{l}\text { Housing as type of CSR } \\
\text { Activity found at TWC }\end{array}$ & 96 & 2.04 & 1.015 \\
\hline $\begin{array}{l}\text { Village Adoption as type of } \\
\text { CSR Activity found at TWC }\end{array}$ & 96 & 3.45 & .806 \\
\hline $\begin{array}{l}\text { Community Involvement as } \\
\text { type of CSR Activity found at } \\
\text { TWC }\end{array}$ & 96 & 3.61 & .655 \\
\hline $\begin{array}{l}\text { Employment and } \\
\text { Employability as type of CSR } \\
\text { Activity found at TWC }\end{array}$ & 96 & 3.48 & .781 \\
\hline $\begin{array}{l}\text { Rural Sports as type of CSR } \\
\text { Activity found at TWC }\end{array}$ & 96 & 1.95 & 1.030 \\
\hline $\begin{array}{l}\text { Welfare as type of CSR } \\
\text { Activity found at TWC }\end{array}$ & 96 & 3.59 & .762 \\
\hline Valid N (listwise) & 96 & & \\
\hline
\end{tabular}

From the Table 4.3 above it can be seen that some items used to measure types of CSR activities were rated by the participants by looking the basic statistics like mean and standard deviations. The most items were positively rated by the participants. The subsequent sections present the findings for items which were used to assess the types of CSR found at TWC. The mean ranges from 1 to 4 where by 1 stands for strongly disagree, 2 stands for disagree, 3 stands agree and 4 for strongly agree.

To determine whether respondents agreed on the items used to 


\section{Dr. David A. O. Aunga et al / The Impact of Corporate Social Responsibility on Corporate Financial Perfomance in Tanganyika Wilderness Camps Limited in Arusha Region, Tanzania}

measure the percentage of those agreeing on specific issues; the mean had happened to have the range between 1 and 4 . Where the responses with lower mean value were considered to have a less responses from the participants and those with mean approaching to 4 were considered to represent the positive opinions from the participants of the study. The study revealed that types of CSR with the mean of above 2.49 that means they agreed to Environmental care as type of CSR Activity found at TWC, Education as type of CSR Activity found at TWC, Health Care as type of CSR Activity found at TWC, Peripheral Development as type of CSR Activity found at TWC, Village Adoption as type of CSR Activity found at TWC, Employment and Employability as type of CSR Activity found at TWC as well as Welfare as type of CSR Activity found at TWC as presented in the figure above. The study also revealed that Rural Sports as type of CSR Activity found at TWC read the mean of 1.95 which shows that most of the respondents disagreed to it.

A study by Gathungu and Ratemo (2013) revealed that disclosure of the CSR activities by organizations was used as a measurement tool of performance in the sense that the investment in CSR activities was an indication of the level of resources available and more especially the value that the organization had ascribed to the beneficiaries of the programs.

The following table illustrates their respondents below using frequency and percentage.

\section{i. Environmental Care}

From the study conducted by the researcher it was found that $50(52.1 \%)$ of the respondents strongly agreed that environmental care is one of the type of CSR activity found at TWC whereby $25(26 \%)$ agreed, $12(12.5 \%)$ disagreed while the remaining $9(9.4 \%)$ strongly disagreed that environmental care is not one of the type of CSR activity found at TWC. Various other studies were conducted to evaluate the relationship between corporate responsibility and financial performance. They produced mixed results: (Konar and Cohen, 2001) positive relationship, this research founded a positive correlation exists between a firm's environmental performance and its intangible asset value. The study was conducted on 321 manufacturing firms of the S \& P 500 firms. They employed two environmental performance measures namely Toxic Release Inventory (TRI) emission levels and pending environment-related litigation. Changes in the intangible asset value were estimated by viewing changes in the firm's market value. The study also found out that a reduction in the toxic chemical release to the environment resulted in increased market value for the firm. Moreover, (Holmes, 2002) had defined aspects of property related CSR as primarily connected to environmental sustainability as well as elements of ethical and social responsibility. While (Adair and Lay, 2003) pointed out that related CSR property in the United Kingdom has the tendency to focus on environmental issues, particularly in creating environmentally sustainable new building and controlling energy usage; nevertheless they emphasized less on the social and community aspects. Hence, environment as a CSR activity is one of the best practices to implement since it has positive result to the firm by even referring to the supportive literature above. Table 4.4 shows:

Table 4.4: Environmental Care

\begin{tabular}{|l|l|l|}
\hline Response & Frequency & Percent $(\boldsymbol{\%})$ \\
\hline Strongly Agree & 50 & 52.1 \\
\hline Agree & 25 & 26.0 \\
\hline Disagree & 12 & 12.5 \\
\hline Strongly Disagree & 9 & 9.4 \\
\hline Total & $\mathbf{9 6}$ & $\mathbf{1 0 0 . 0}$ \\
\hline
\end{tabular}

\section{ii. Education}

According to the table below, the study data revealed that 64 $(66.7 \%)$ of the respondents strongly agreed that Education is one of the type of CSR activity found at TWC whereby $32(33.3 \%)$ whilst $0(0 \%)$ disagreed and strongly disagreed respectively. Prior researches have been done to examine customer reaction towards sponsoring firm or brand, Results from survey by (Smith and Alcorn, 1991) shows that $56 \%$ of the consumers support the importance of the contribution to the education from CSR. This proves vividly that TWC uses education as one of the CSR activity a lot to ensure community development as well as recognition in the surrounding community. Table 4.5 below shows:

\section{Table 4.5: Education}

\begin{tabular}{|l|l|l|}
\hline Response & Frequency & Percent $(\boldsymbol{\%})$ \\
\hline Strongly Agree & 64 & 66.7 \\
\hline Agree & 32 & 33.3 \\
\hline Disagree & 0 & 0 \\
\hline Strongly Disagree & 0 & 0 \\
\hline Total & $\mathbf{9 6}$ & $\mathbf{1 0 0 . 0}$ \\
\hline
\end{tabular}

\section{iii. Healthcare}

The study data revealed that $37(38.5 \%)$ of the respondents strongly agreed that health care is also one of the CSR activity practiced by the organization, $25(26 \%)$ agreed, $18(18.8 \%)$ disagreed while the remaining $16(16.7 \%)$ strongly disagreed to that concept. Table 4.6 show:

Table 4.6: Healthcare

\begin{tabular}{|l|l|l|}
\hline Response & Frequency & Percent $(\%)$ \\
\hline Strongly Agree & 37 & 38.5 \\
\hline Agree & 25 & 26 \\
\hline Disagree & 18 & 18.8 \\
\hline Strongly Disagree & 16 & 16.7 \\
\hline Total & $\mathbf{9 6}$ & $\mathbf{1 0 0 . 0}$ \\
\hline
\end{tabular}

\section{iv. Peripheral Development}

The table below shows data obtained from the study in regarding to if Peripheral Development is one of the activities also practiced by TWC. The study revealed that $47(49 \%)$ strongly agreed, 29(30.1\%) agreed whilst 2(2.1\%) disagreed 
and the remaining $18(18.75 \%)$ strongly disagreed that Peripheral Development is not one of the activity also practiced by TWC. Table 4.7 below shows:

Table 4.7: Peripheral Development

\begin{tabular}{|l|l|l|}
\hline Response & Frequency & Percent $(\%)$ \\
\hline Strongly Agree & 47 & 49 \\
\hline Agree & 29 & 30.1 \\
\hline Disagree & 2 & 2.1 \\
\hline Strongly Disagree & 18 & 18.75 \\
\hline Total & $\mathbf{9 6}$ & $\mathbf{1 0 0 . 0}$ \\
\hline
\end{tabular}

\section{v. Housing}

The study data revealed that $13(13.5 \%)$ of the respondents strongly agreed on housing as one of the organizations CSR activity, $12(12.5 \%)$ agreed, $37(38.5 \%)$ disagreed while the remaining $34(35.5 \%)$ strongly disagreed. The Deputy Minister in the Prime Minister Department suggested that housing developers should implement CSR by giving maximum consideration to protect the environment in carrying out development, providing social amenities for the children and senior citizens, providing sports and recreational facilities, as well as providing facilities to encourage social interaction among the residents (New Straits Times, 11 December 2004).This proves vividly that TWC doesn't practice housing as one the corporate social responsibility activity. Table 4.8 below shows:

\section{Table 4.8: Housing}

\begin{tabular}{|l|l|l|}
\hline Response & Frequency & Percent $(\boldsymbol{\%})$ \\
\hline Strongly Agree & 13 & 13.5 \\
\hline Agree & 12 & 12.5 \\
\hline Disagree & 37 & 38.5 \\
\hline Strongly Disagree & 34 & 35.5 \\
\hline Total & $\mathbf{9 6}$ & $\mathbf{1 0 0 . 0}$ \\
\hline
\end{tabular}

\section{vi. Village adoption}

The table below shows data obtained from the study in regarding to if Tanganyika Wilderness Camps do village adoption as their CSR activity. The study revealed that $56(58.3 \%)$ strongly agreed, 33(34.4\%) agreed whilst $1(1 \%)$ were those who disagreed and the remaining 6(6.3) of the respondents strongly disagreed. This also proves that TWC is well doing practicing village adoption as one of their CSR activity. Table 4.9 below illustrates:

\section{Table 4.9: Village adoption}

\begin{tabular}{|l|l|l|}
\hline Response & Frequency & Percent $\mathbf{( \% )}$ \\
\hline Strongly Agree & 56 & 58.3 \\
\hline Agree & 33 & 34.4 \\
\hline Disagree & 1 & 1 \\
\hline Strongly Disagree & 6 & 6.3 \\
\hline Total & $\mathbf{9 6}$ & $\mathbf{1 0 0 . 0}$ \\
\hline
\end{tabular}

\section{vii. Community Involvement}

According to the table below, the study data revealed that 66 $(68.8 \%)$ of the respondents strongly agreed that community involvement is one of the type of CSR activity found at TWC whereby $25(26 \%)$ agreed whilst $3(3.1 \%)$ disagreed and 2 (2.1\%) strongly disagreed. This proves vividly that TWC practice community involvement as one of the CSR activity a lot to ensure community development as well as recognition in the surrounding community. Watts (2004) states that CSR is the continuing commitment by business to behave ethically and contribute to economic development while improving the quality of life of the workforce and their families as well as the society at large. Businesses must not only be in business for the business but must also be in business for the community in which it operates, which means it must be concerned about the welfare and wellbeing of the society. Table 4.10 illustrates:

Table 4.10: Community Involvement

\begin{tabular}{|l|l|l|}
\hline Response & Frequency & Percent $(\boldsymbol{\%})$ \\
\hline Strongly Agree & 66 & 68.8 \\
\hline Agree & 25 & 26 \\
\hline Disagree & 3 & 3.1 \\
\hline Strongly Disagree & 2 & 2.1 \\
\hline Total & $\mathbf{9 6}$ & $\mathbf{1 0 0 . 0}$ \\
\hline
\end{tabular}

viii. Employment \& Employability

The study data revealed that $61(63.5 \%)$ of the respondents strongly agreed that TWC practice Employment \& Employability as one of their CSR activities, 22(22.9\%) agreed while $11(11.5 \%)$ disagreed and the remaining $2(2.1 \%)$ strongly disagreed. Borb6ly (2003) views CSR as a continuing commitment by corporate citizens to act ethically, contributing towards economic development while improving the quality of life of their employees and also the whole community and society at large. According to the frequency and percentage presented in this section, this shows vividly that TWC care much about employment and does it frequently to cover the gap of unemployment in Tanzania. Table 4.11 shows:

Table 4.11: Employment\& Employability

\begin{tabular}{|l|l|l|}
\hline Response & Frequency & Percent $\mathbf{( \% )}$ \\
\hline Strongly Agree & 61 & 63.5 \\
\hline Agree & 22 & 22.9 \\
\hline Disagree & 11 & 11.5 \\
\hline Strongly Disagree & 2 & 2.1 \\
\hline Total & $\mathbf{9 6}$ & $\mathbf{1 0 0 . 0}$ \\
\hline
\end{tabular}

ix. Rural Sports

The study data revealed that rural sports is practiced only by $10(10.4 \%)$ who were those who strongly agree, $18(18.8 \%)$ agreed, 25(26\%) disagreed while the remaining $43(44.8 \%)$ strongly disagreed. According to the frequency and percentage presented in this section, this shows vividly that the organization doesn't support rural support as one of their 
CSR activity. Though TWC doesn't support rural sport but according to Lo \& Yap, 2011 states that $97.5 \%$ of the 198 respondents agreed that Malaysian companies do engage in CSR activities. The areas of CSR include employees welfare, responsive to customer complaints, maintaining product/service quality to customers, ensuring product safety, donation to welfare organizations, giving guarantee policy or warranty provisions, contributing towards games, sports, culture and literacy work, providing jobs for the handicapped, contributing to education institutions, lending a helping hand to overcome drug-abuse problems, granting loans to low income housing, providing loans to small enterprises, contributing towards public amenities, and involving in crime prevention (Lo \& Yap, 2011). Table 4.12 shows:

Table 4.12: Rural Sports

\begin{tabular}{|l|l|l|}
\hline Response & Frequency & Percent $(\boldsymbol{\%})$ \\
\hline Strongly Agree & 10 & 10.4 \\
\hline Agree & 18 & 18.8 \\
\hline Disagree & 25 & 26 \\
\hline Strongly Disagree & 43 & 44.8 \\
\hline Total & $\mathbf{9 6}$ & $\mathbf{1 0 0 . 0}$ \\
\hline
\end{tabular}

\section{x. Welfare}

The study data revealed that $68(70.8 \%)$ of the respondents strongly agreed that welfare is also one of the CSR activity practiced by the organization, 22(22.9\%) agreed, 1 (1\%) disagreed while the remaining $5(5.3 \%)$ strongly disagreed to that concept. This also proves that welfare is really a CSR activity practiced in this organization. Table 4.13 illustrates:

Table 4.13: Welfare

\begin{tabular}{|l|l|l|}
\hline Response & Frequency & Percent $(\%)$ \\
\hline Strongly Agree & 68 & 70.8 \\
\hline Agree & 22 & 22.9 \\
\hline Disagree & 1 & 1 \\
\hline Strongly Disagree & 5 & 5.3 \\
\hline Total & $\mathbf{9 6}$ & $\mathbf{1 0 0 . 0}$ \\
\hline
\end{tabular}

Graphical presentation of the types of Cooperate social responsibility (CSR) activities towards corporate financial performance (CSP) in TWC, figure 4.3 below shows:

Figure 4.3: Types of Cooperate social responsibility (CSR)

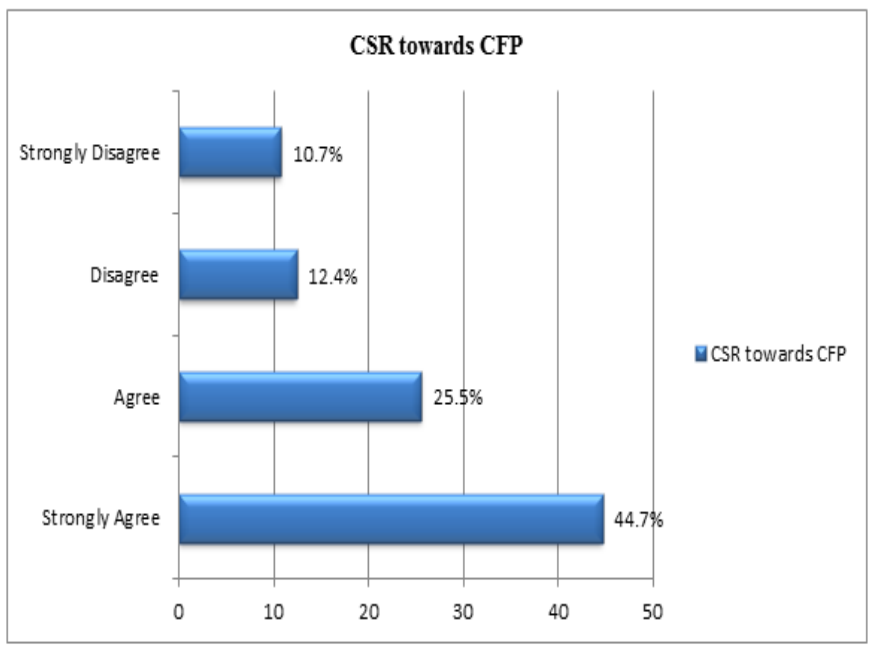

To determine the level of relationship between Cooperate social responsibility (CSR) and corporate financial performance (CFP) in TWC.

The researcher was interested to determine the relationship between Cooperate social responsibility (CSR) and corporate financial performance (CFP) in TWC. The data from the study shows that there is positive relationship between CSR and CFP at TWC. Respondents strongly agreed by $49.65 \%$, agreed by $30.9 \%$, disagreed by $6.2 \%$ and strongly disagreed by $13.2 \%$ that there is relationship between Cooperate social responsibility (CSR) and corporate financial performance (CFP) in TWC. According to the questionnaire, the data from the field revealed that $53(55.2 \%)$ of the respondents strongly agreed Cooperate social responsibility promotes long-term profits for business, 25(26.04\%) agreed, 12(12.5\%) disagreed while the remaining $6(6.25 \%)$ strongly disagreed, 45 (46.88\%) of the respondents strongly agreed that Cooperate social responsibility stimulates and sustains customer demand, $22(22.91 \%)$ agreed, 11(11.46) disagreed while the remaining $18(18.75 \%)$ strongly disagreed. By adding value to society, firms realize that they can transcend from doing good to doing better in order to survive and compete in the competitive global market (Lin, Yang \& Liou, 2009).

$54(56.25 \%)$ of the respondents strongly agreed that CSR Serves as a source of competitive advantage, 36(37.5\%) agreed, $0(0 \%)$ disagreed while the remaining $6(6.25 \%)$ strongly disagreed to that concept that it Serves as a source of competitive advantage. Watts (2003) found that firms with high CSP attracted more socially responsible consumers and experienced improved financial performance. The study data also revealed that respondents strongly agree by $35(36.36 \%)$ that corporate social responsibility attracts investors, 28 (29.17\%) were those who agree, 12 (12.5\%) disagreed while $21(21.87 \%)$ strongly disagreed. According to the frequency and percentage presented in this section, this shows vividly that the organization has positive relation between CSR and CFP. (McWilliams and Siegel, 2001) suggest that CSR involvement can attract investors and improve firm financial performances and thus, decision related to expenditure on CSR activities need to evaluate and analyse just like other investment decisions. 
Moreover, the study data revealed that $58(60.4 \%)$ of the respondents strongly agreed that Cooperate social responsibility Improves business image and reputation, $34(35.4 \%)$ agreed, $0(0 \%)$ disagreed while the remaining 4 (4.2\%) strongly disagreed. Porter and Krammer (2011) indicates that addressing social concerns could increase the levels of company productivity, with subsequent positive effects on profitability, share value and company image. To ensure that companies continue to improve their business image and reputation, according to their Newsletter, Unki CED Newsletter (2013) UM has invested US\$ 1 Million in community projects in 2013. In 2012 the researcher found out that UM made donations to the community of $\$ 21,183.00$. The study data revealed that respondents strongly agree by $41(42.7 \%)$ that corporate social responsibility enhances core business activities, 33(34.4\%) were those who agree, $1(1 \%)$ disagreed while 21(21.9\%) strongly disagreed.

Relationship between Corporate social responsibility (CSR) and corporate financial performance (CFP)

\begin{tabular}{|l|l|l|l|}
\hline & N & Mean & $\begin{array}{l}\text { Std. } \\
\text { Deviation }\end{array}$ \\
\hline $\begin{array}{l}\text { It promotes long-term } \\
\text { profits for business }\end{array}$ & 96 & 3.30 & .919 \\
\hline $\begin{array}{l}\text { Stimulates and sustains } \\
\text { customer demand }\end{array}$ & 96 & 2.98 & 1.161 \\
\hline $\begin{array}{l}\text { Serves as a source of } \\
\text { competitive advantage }\end{array}$ & 96 & 3.44 & .792 \\
\hline $\begin{array}{l}\text { Attracts investors } \\
\begin{array}{l}\text { Improves business image } \\
\text { and reputation }\end{array}\end{array}$ & 96 & 3.52 & 1.157 \\
\hline $\begin{array}{l}\text { Enhances core business } \\
\text { activities }\end{array}$ & 96 & 2.98 & 1.151 \\
\hline Valid N (listwise) & 96 & & \\
\hline
\end{tabular}

From the Table 4.14 above it can be seen that some items used to measure relationship between corporate social responsibility (CSR) and corporate financial performance (CFP) were rated by the participants by looking the basic statistics like mean and standard deviations. All items were positively rated by the participants. The subsequent sections present the findings for items which were used to assess the types of CSR found at TWC. The mean ranges from 1 to 4 where by 1 stands for strongly disagree, 2 stands for disagree, 3 stands agree and 4 for strongly agree.

To determine whether respondents agreed on the items used to measure the percentage of those agreeing on specific issues; the mean had happened to have the range between 1 and 4 . Where the responses with lower mean value were considered to have a less responses from the participants and those with mean approaching to 4 were considered to represent the positive opinions from the participants of the study. The study revealed that there is a positive relationship between CSR and CFP as it can be seen that all the mean read above 2.5.

The table 4.14 above presented the total number of all the respondents, mean and std. deviation of relationship between Cooperate social responsibility (CSR) and corporate financial performance (CFP), the smaller the std. deviation to the mean proves how close the relationship is between the two variables. The data was obtained from the general overview of all the variables presented in this objective. According to the frequency and percentage presented in this section, this shows vividly that the organization has positive relation between CSR and CFP

\section{i. It promotes long-term profits for business}

According to the table below, the study data revealed that 53 $(55.2 \%)$ of the respondents strongly agreed Cooperate social responsibility promotes long-term profits for business, $25(26.04 \%)$ agreed, 12(12.5\%) disagreed while the remaining $6(6.25 \%)$ strongly disagreed. Lorraine (2009) realized that a commonality among them was that CSR was generally defined by reference to stakeholder theory in that a firm was socially responsible if it took into account the interests and needs of its group of stakeholders and that CSR activities are positively correlated with firm size. CSR is strictly embedded with a multitude of business actors. CSR ensures sustainability and the new role of business in society (Blowfield \& Googins, 2006), and with increased expectations and new rules and tactics (Burke, 2005). From the data obtained from the study, this proves vividly that CSR promotes long terms profits for business even from the above supportive literature. The table 4.15 below illustrates:

Table 4.15: It promotes long-term profits for business

\begin{tabular}{|l|l|l|}
\hline Response & Frequency & Percent $(\%)$ \\
\hline Strongly Agree & 53 & 55.2 \\
\hline Agree & 25 & 26.04 \\
\hline Disagree & 12 & 12.5 \\
\hline Strongly Disagree & 6 & 6.25 \\
\hline Total & $\mathbf{9 6}$ & $\mathbf{1 0 0 . 0}$ \\
\hline
\end{tabular}

\section{ii. Stimulates and sustains customer demand}

Table 4.16 below shows that $45(46.88 \%)$ of the respondents strongly agreed that Cooperate social responsibility stimulates and sustains customer demand, 22(22.91\%) agreed, 11(11.46) disagreed while the remaining $18(18.75 \%)$ strongly disagreed. By adding value to society, firms realize that they can transcend from doing good to doing better in order to survive and compete in the competitive global market (Lin, Yang \& Liou, 2009).

Table 4.16: Stimulates and sustains customer demand

\begin{tabular}{|l|l|l|}
\hline Response & Frequency & Percent $(\%)$ \\
\hline Strongly Agree & 45 & 46.88 \\
\hline Agree & 22 & 22.91 \\
\hline Disagree & 11 & 11.46 \\
\hline Strongly Disagree & 18 & 18.75 \\
\hline Total & $\mathbf{9 6}$ & $\mathbf{1 0 0 . 0}$ \\
\hline
\end{tabular}




\section{Dr. David A. O. Aunga et al / The Impact of Corporate Social Responsibility on Corporate Financial Perfomance in Tanganyika Wilderness Camps Limited in Arusha Region, Tanzania}

\section{iii. Serves as a source of competitive advantage}

Table 4.17 below shows that $54(56.25 \%)$ of the respondents strongly agreed that CSR Serves as a source of competitive advantage, $36(37.5 \%)$ agreed, $0(0 \%)$ disagreed while the remaining $6(6.25 \%)$ strongly disagreed to that concept that it Serves as a source of competitive advantage. Watts (2003) found that firms with high CSP attracted more socially responsible consumers and experienced improved financial performance. Another reason management may address these concerns is because CSR may serve as a strategy to create and maintain a competitive advantage. By adding value to society, firms realize that they can transcend from doing good to doing better in order to survive and compete in the competitive global market (Lin, Yang \& Liou, 2009). This shows that there is a positive relationship between CSR and CFP at Tanganyika Wilderness Camps.

Table 4.17: Serves as a source of competitive advantage

\begin{tabular}{|l|l|l|}
\hline Response & Frequency & Percent $(\%)$ \\
\hline Strongly Agree & 54 & 56.25 \\
\hline Agree & 36 & 37.5 \\
\hline Disagree & 0 & 0 \\
\hline Strongly Disagree & 6 & 6.25 \\
\hline Total & $\mathbf{9 6}$ & $\mathbf{1 0 0 . 0}$ \\
\hline
\end{tabular}

\section{iv. Attracts investors}

Table 4.18 below revealed that respondents strongly agree by $35(36.36 \%)$ that corporate social responsibility attracts investors, 28(29.17\%) were those who agree, $12(12.5 \%)$ disagreed while $21(21.87 \%)$ strongly disagreed. According to the frequency and percentage presented in this section, this shows vividly that the organization has positive relation between CSR and CFP. McWilliams and Siegel, 2001 suggest that CSR involvement can attract investors and improve firm financial performances and thus, decision related to expenditure on CSR activities need to evaluate and analyse just like other investment decisions. Other contemporary authors defend shareholder value maximization as the one objective function to all companies but are not necessarily against the social responsibility actions by companies (Jensen, 2001); Coelho et al., (2003).

\section{Table 4.18: Attracts investors}

\begin{tabular}{|l|l|l|}
\hline Response & Frequency & Percent $(\%)$ \\
\hline Strongly Agree & 35 & 36.46 \\
\hline Agree & 28 & 29.17 \\
\hline Disagree & 12 & 12.5 \\
\hline Strongly Disagree & 21 & 21.87 \\
\hline Total & $\mathbf{9 6}$ & $\mathbf{1 0 0 . 0}$ \\
\hline
\end{tabular}

\section{v. Improves business image and reputation}

From the table 4.19 below, the study data revealed that 58 $(60.4 \%)$ of the respondents strongly agreed that Cooperate social responsibility Improves business image and reputation,
$34(35.4 \%)$ agreed, $0(0 \%)$ disagreed while the remaining 4 (4.2\%) strongly disagreed. Porter and Krammer (2011) indicates that addressing social concerns could increase the levels of company productivity, with subsequent positive effects on profitability, share value and company image. To ensure that companies continue to improve their business image and reputation, According to their Newsletter, Unki CED Newsletter (2013) UM has invested US\$ 1 Million in community projects in 2013. In 2012 the researcher found out that UM made donations to the community of $\$ 21183.00$. Fritz (2009) argues that organizations today are getting involved in CSR to enhance their company image. It is often argued that the reason why corporations engage in CSR is a certain level of self-interest, not considering if the act is strategically motivated by commercial reasons alone or whether it is also motivated by what might seem as an altruistic interest, (Moon 2001). (Veradajan and Menon, 2002) states that there are several objectives of CSR for corporate giving beyond altruism. Companies seek to enhance their image in order to create a positive reputation that may also relate to higher long-run organizational performance. More CSR practices leads to an improved (or at least maintained) reputation, which causes the firm to continue to be a target of activism, the consequence of which is more commitment to CSR. From the point of view of the company, however, having a good reputation can be a "double edged sword" or at least a potential liability when facing activists who seek the public limelight, (Rhee and Haunschild 2006). Corporate social responsibility (CSR) has become an important focus of attention among companies. A McKinsey global survey shows that $76 \%$ of executives believe that corporate social responsibility contributes positively to long-term shareholder value, and $55 \%$ of executives agree that sustainability helps their companies build a strong reputation, (McKinsey 2010).

Table 4.18: Improves business image and reputation

\begin{tabular}{|l|l|l|}
\hline Response & Frequency & Percent $(\%)$ \\
\hline Strongly Agree & 58 & 60.42 \\
\hline Agree & 34 & 35.4 \\
\hline Disagree & 0 & 0 \\
\hline Strongly Disagree & 4 & 4.2 \\
\hline Total & $\mathbf{9 6}$ & $\mathbf{1 0 0 . 0}$ \\
\hline
\end{tabular}

\section{vi. Enhances core business activities}

The study data revealed that respondents strongly agree by $41(42.7 \%)$ that corporate social responsibility enhances core business activities, 33(34.4\%) were those who agree, $1(1 \%)$ disagreed while $21(21.9 \%)$ strongly disagreed. According to the frequency and percentage presented in this section, this shows vividly that the organization has positive relation between CSR and CFP. (Classon and Dahlstrom, 2006) under the title "By what means can CSR Affect Company Performance?" expound that how CSR influence the client discernment which has evident effect on budgetary execution of the organizations. Garments Industry was utilized as 
populace for discoveries of exploration. 15 organizations were picked as their specimen. Meetings were held for accumulation of information. Qualitative measures were utilized for information investigation. The models were created for CSR (quality joining chain) and CFP (Service benefit chain) They presume that organizations ought to include in moral exercises on the off chance that they need to attain the great client observation and construct a decent picture in client's brain to accomplish the high benefits. Table 4.19 illustrates:

Table 4.19: Enhances core business activities

\begin{tabular}{|l|l|l|}
\hline Response & Frequency & Percent $\mathbf{( \% )}$ \\
\hline Strongly Agree & 41 & 42.7 \\
\hline Agree & 33 & 34.4 \\
\hline Disagree & 1 & 1 \\
\hline Strongly Disagree & 21 & 21.9 \\
\hline Total & $\mathbf{9 6}$ & $\mathbf{1 0 0 . 0}$ \\
\hline
\end{tabular}

Graphical presentation of the relationship between CSR and CFP at TWC.

Figure 4.4: Relationship between CSR AND CFP at TWC

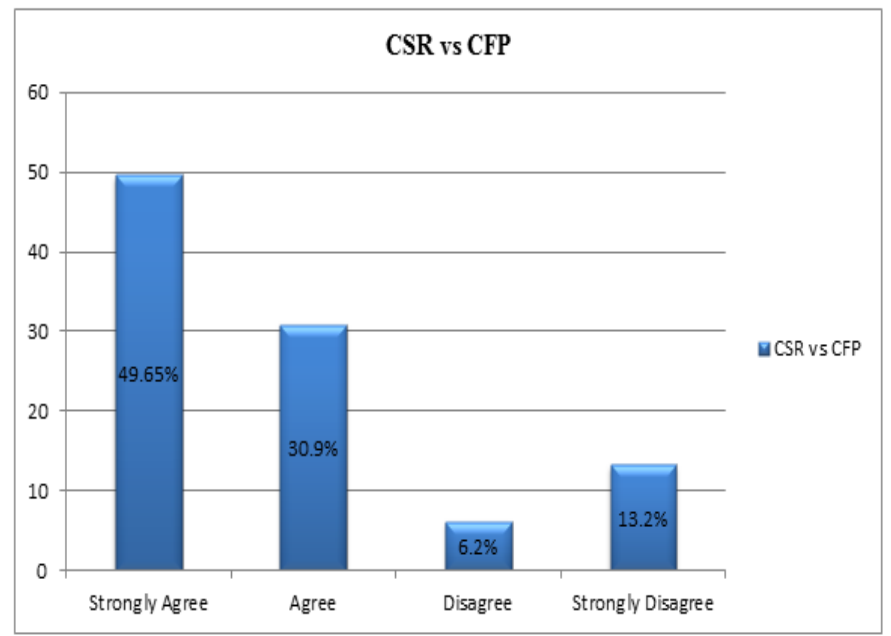

4.5 To assess the impact of corporate social responsibility practices on financial performance in TWC.

To meet this objective, reports and financial statements for the year ended $31^{\text {st }}$ December 2015 were assessed to reveal how the firm engages itself in supporting CSR activities as well as identifying and assessing it impacts on financial performance of the firm. Vividly, it has been seen that TWC practises some of the CSR activities which shows it positive relationship with the firm financial performance as per appendix (booklets) attached at the end of this paper.

The firm CSR activity performed highly as noted in the financial reports books shows that employee welfare was one of them. There was good relation between employees and management for the year 2015. There were unresolved complaints received by management from the employees during the year, but the company offers an equal opportunity to employees, financial help and a benefit plan. A healthy relationship continues to exist between management and employees, and this affects the firm financial performance directly, as it is noted that employees are the best appreciating asset a company can have. Hence, employees at TWC enabled the positive relationship between CSR and CFP.

To honour its social responsibilities to the community in which the company operates, the company made a total donation of TZS86 million in 2015 and TZS 15 million in 2014 to the community development projects. Figure 4.5 below illustrates the above explanations.

Figure 4.5 TWC Donation for the year 2014 and 2015.

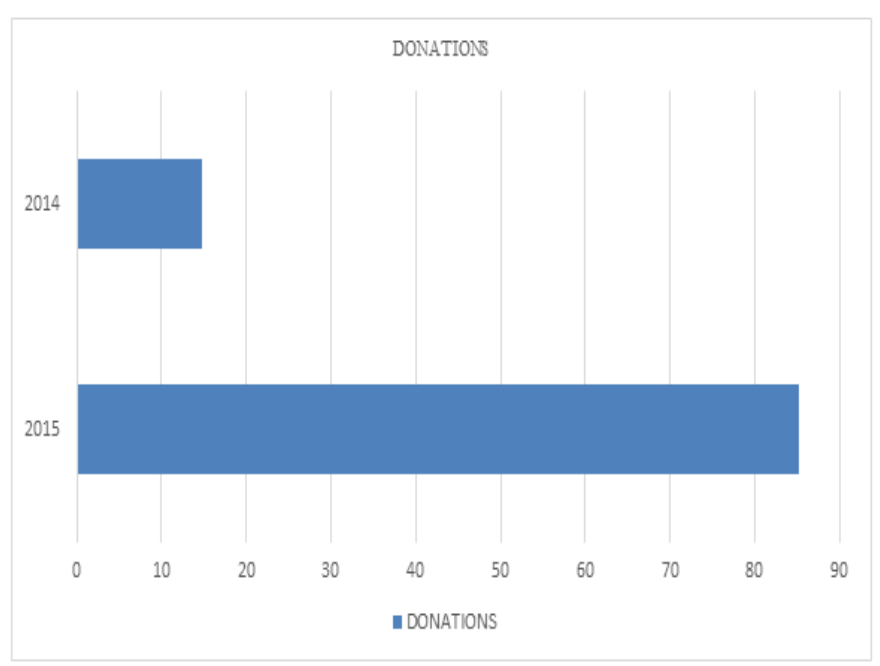

As per attached appendix on this paper regarding this objective, more information will be referred there.

Measurement on ROA and ROI as how they affect CSR on the firm financial performance.

From the result, it shows that CSR has direct relationship with both ROA and ROE for this model. This result indicates, for ROA, every unit increase in CSR, firm ROA will increase, meanwhile for ROE, every unit increase in CSR, firm ROE will increase. This result support there is strong and positive relationship between CSR with ROA and ROA.

\section{a) ROA}

The return on assets ratio formula is calculated by dividing net income by average total assets. This ratio can also be represented as a product of the profit margin and the total asset turnover. Either formula can be used to calculate the return on total assets. The net income can be found on the income statement as per attached appendix in this paper.

Tanganyika Wilderness Camps (TWC) Company is a tourism company that provides tourism services to its client. Tanganyika Wilderness Camps (TWC) balance sheet shows 22,086,572,000 TZS billions of Total assets. During the year Of 2015, Tanganyika Wilderness Camps (TWC) Company had net income of $1,167,850,000$ TZS billions. Tanganyika Wilderness Camps (TWC) return on assets ratio looks like this.

ROA $=$ Net Profit after tax/sales x sales/ Total Assets

Whereby, 
Dr. David A. O. Aunga et al / The Impact of Corporate Social Responsibility on Corporate Financial Perfomance in Tanganyika Wilderness Camps Limited in Arusha Region, Tanzania

Profit margin=net profit after taxes/sales

Total Asset turnover=sales/total assets

TWC revenue for the year $2015=15,696,606,000$

TWC net profit after taxes for the year $2015=1,167,850,000$

TWC total assets as at 31/12/2015=22,086,572,000

Profit margin $=1,167,850,000 / 15,696,606,000$

Profit margin $=0.0744$

Profit margin $=0.0744 \times 100=7.44 \%$

This means that TWC converted 7.44 percent of her sales into profits. In other words, it measures how much profits are produced at a certain level of sales.

Total asset turnover $=15,696,606,000 / 22,086,572,000$

Total asset turnover $=0.7107$

Total asset turnover $=0.7107 \times 100=71.07 \%$

$\mathrm{ROA}=$ Profit margin Total assets turnover

$\mathrm{ROA}=7.44 \% \times 71.07 \%$

$\mathrm{ROA}=528.7608 \%$

As you can see TWC ROA is $528.7608 \%$ In other words, every Shilling that TWC invested in assets during the year produced TZS 5.28 of net income. Depending on the economy, this can be a healthy return rate no matter what the investment is

b) $\mathrm{ROE}$

Return on equity (ROE) is the amount of net income returned as a percentage of shareholder's equity. Return on equity measures a corporation's profitability by revealing how much profit a company generates with the money shareholders have invested. ROE is expressed as a percentage and calculated as:

Return on Equity = Net Income/Shareholder's equity

\section{BREAKING DOWN}

'Return on Equity - ROE' The ROE is useful for comparing the profitability of a company to that of other firms in the same industry. TWC Net income by the year end $31^{\text {st }}$ of December was $1,167,850,000 \mathrm{TZS}$.

As per formula below, the ROE in TWC reads as follows:

Return on Equity = Net Income after tax/Shareholder's equity

Shareholders equity $=$ Total asset - Total liabilities

TWC total asset as at $31 / 12 / 2015=22,086,572,000 \mathrm{TZS}$

TWC total liabilities as at $31 / 12 / 2015=12,186,490,000 \mathrm{TZS}$

Shareholders

$$
\text { equity }=22,086,572,000
$$

$12,186,490,000=9,900,082,000 \mathrm{TZS}$

Shareholders equity $=9,900,082,000$ TZS

TWC have a positive impact of 9,900,082,000 TZSwhich means that a company have more than enough assets to cover all its liabilities which gives TWC the safe investment choice.

Whereby,

Return on Equity = Net Income after tax/Shareholder's equity

Net Income after tax $=1,167,850,000$ TZS

Shareholders Equity= 9,900,082,000 TZS

$\mathrm{ROE}=1,167,850,000 / 9,900,082,000$

$\mathrm{ROE}=0.11796$

$\mathrm{ROE}=0.11796 \mathrm{X} 100=11.796 \%$

$\mathrm{ROE}=11.796 \%$

The above calculation proves positive relationship of $\mathrm{ROE}$ with CSR activities performed at TWC. That in every activity conducted by the company there is a profit of $11.796 \%$ for every income that is earned per the year 2015 including that CSR activities are performed by the company.

CSR Activities performed by TWC by the year end $31^{\text {st }}$ 2015 by the amount spent on every area and how it affects the firm's financial performance.

a. Staff Welfare $=12,194,000 \mathrm{TZS}$

b. Donations and Subscription $=108,541,000 \mathrm{TZS}$

c. Village camping and Maasai fees $=140,060,000 \mathrm{TZS}$

d. $\quad$ Staff Training $=19,895,000$ TZS

e. Environmental Conservation $=6,688,000 \mathrm{TZS}$

f. Employment \& Employability (salaries) = $1,496,855,000 \mathrm{TZS}$

g. NSSF \& NHIF $=152,065,000 \mathrm{TZS}$

h. Bonus and Other Incentives $=213,226,000 \mathrm{TZS}$

i. Skills development levy $=99,796,000 \mathrm{TZS}$

j. $\quad$ Staff medical expenses $=25,934,000 \mathrm{TZS}$

The above CSR activities were found practiced at TWC and it shows how much the firm is putting its effort in supporting social responsibilities as well as staff's wellbeing. See figure 4.6 bellow.

Figure 4.6: CSR Activities at TWC CSR ACTIVITIES AT TWC

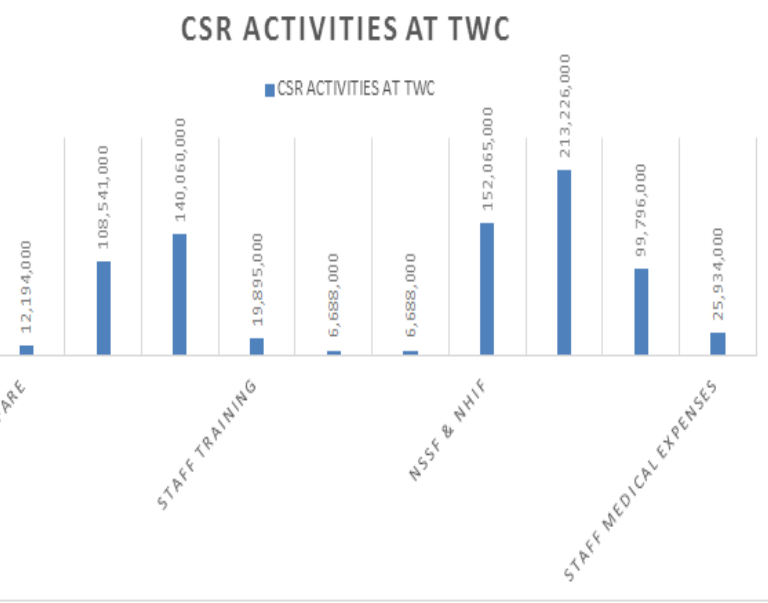

The total amount of money that TWC spent on its CSR activities in the year 2015 is $785,087,000 \mathrm{TZS}$ as presented on 


\section{Dr. David A. O. Aunga et al / The Impact of Corporate Social Responsibility on Corporate Financial Perfomance in Tanganyika Wilderness Camps Limited in Arusha Region, Tanzania}

the figure above that shows the activities performed by the firm. By the above explanations, the researcher find no doubt on CSR relationship with CFP at TWC, since the data above prove vividly that there is a positive relationship between the two and according to the financial report attached as appendix III in this dissertation shows that these CSR activities does not affect the firm's financial performance negatively.

\section{SUMMARY, CONCLUSION AND RECOMMENDATIONS}

\section{Summary of Findings}

The purpose of this study was to examine the impacts of corporate social responsibility (CSR) on corporate financial performance (CSP) at Tanganyika Wilderness Camps (TWC) in Arusha region. The study considered all groups of the respondents from the organization surveyed.

1 Types of Cooperate social responsibility (CSR) activities towards corporate financial performance (CSP) in TWC.

The study revealed that types of CSR with the mean of above 2.49 that means they agreed to Environmental care as type of CSR Activity found at TWC, Education as type of CSR Activity found at TWC, Health Care as type of CSR Activity found at TWC, Peripheral Development as type of CSR Activity found at TWC, Village Adoption as type of CSR Activity found at TWC, Employment and Employability as type of CSR Activity found at TWC as well as Welfare as type of CSR Activity found at TWC as presented in the figure above. The study also revealed that Rural Sports as type of CSR Activity found at TWC read the mean of 1.95 which shows that most of the respondents disagreed to it. This shows that TWC practice most of the CSR activities measured in this study.

2 To determines the relationship between Cooperate social responsibility (CSR) and corporate financial performance (CFP) in TWC.

The study revealed that there is a positive relationship between CSR and CFP as it can be seen that all the mean read above

2.5. The study shows total number of all the respondents, mean and std. deviation of relationship between Cooperate social responsibility (CSR) and corporate financial performance (CFP), the smaller the std. deviation to the mean proves how close the relationship is between the two variables. The data was obtained from the general overview of all the variables presented in this objective. According to the frequency and percentage presented in this section as well as the percentages, this shows vividly that the organization have positive relation between CSR and CFP.

3 To assess the impact of corporate social responsibility practices on financial performance in TWC.

To meet this objective, reports and financial statements for the year ended $31^{\text {st }}$ December 2015 were assessed to reveal how the firm engages itself in supporting CSR activities as well as identifying and assessing it impacts on financial performance of the firm. Vividly, it has been seen that TWC practices some of the CSR activities which shows it positive relationship with the firm financial performance as per appendix (booklets) attached at the end of this paper.

The firm CSR activity performed highly as noted in the financial reports books shows that employee welfare was one of them. There were good relation between employees and management for the year 2015. There were unresolved complaints received by management from the employees during the year, but the company offers an equal opportunity to employees, financial help and a benefit plan. A healthy relationship continues to exist between management and employees, and this affects the firm financial performance directly, as it is noted that employees are the best appreciating asset a company can have. Hence, employees at TWC enabled the positive relationship between CSR and CFP.

To honour its social responsibilities to the community in which the company operates, the company made a total donation of TZS86 million in 2015 and TZS 15 million in 2014 to the community development projects. Researcher recommended the reader to see the attached appendix for more verification

\section{Conclusion}

This study identified consequences of corporate social responsibility. From the data revealed from the study, there is a positive relationship between CSR and CFP at TWC and this has helped to affect the firm positively as per appendix III attached at the end of this dissertation regarding financial statements on how the firm engage itself in CSR activities based on director's report and audited financial statements for the year ended $31^{\text {st }}$ December 2015. Data has been collected via structured questionnaires from a tourism company of Arusha. SPSS V20.0 has been used for applying different qualitative data analysis. Based on findings, it is concluded that there are CSR activities found at TWC, the study also revealed that there is a strong relationship between CSR and CFP. CSR is important for improving financial performance of firm. The financial statements also proved to support the two objectives that the company engaged in CSR activities as well as the relationship between CSR and CFP which impact positively the financial performance by measuring ROA and ROE.

\section{Recommendations}

1. From the study, I suggest that companies that involve heavily in CSR practices/activities will have better financial results and receive good responses from institutional investors. Moreover, the company should not blame its low performance on its CSR activities, researcher also recommend that companies should have CSR departments that will be responsible to ensure that social activities are taken on by companies for community betterment and building strong customer loyalty and relationship in return.

2. Companies should engage more in CSR since they affect positively CFP of the firm. The more the company engage 


\section{Dr. David A. O. Aunga et al / The Impact of Corporate Social Responsibility on Corporate Financial Perfomance in Tanganyika Wilderness Camps Limited in Arusha Region, Tanzania}

in these practises the more it achieves better financial performance.

3. CSR has proven to have positive impact on CFP in this study; hence I recommend that companies should not be afraid of investing and giving back to the community. These increases and build a strong relationship between the company and their employees as well as the community.

\section{Future Research}

Based on the few limitations of the above study, the following are some recommendations which should be considered for the future work. The large sample size should be used to interpret the end results instead focusing on only tourism sector. Study could be held in other sectors i.e. automobiles, banks etc. Future studies should use data with a longer period to procure a more valid measurement results. Future studies are expected to connect a Corporate Social Responsibility to the value of the company. Data was collected from tourism company in future researcher can do research on other sectors.

\section{REFERENCE}

Adams, C. A., Hill, W. Y., and Roberts, C. B., 1998. Corporate Social Reporting Practices in Western Europe: Legitimating Corporate Behaviour. The British Accounting Review, 30(1), 1 - 21.

Adams, C., 2002. Internal organisational factors influencing corporate social and ethical reporting. Accounting, Auditing \& Accountability Journal, 15 (2), 223-250.

Ahmed, S. U., Islam, M. Z. and Hasan, I. (2012) "Corporate Social Responsibility and Financial Performance Linkage: Evidence from the Banking Sector of Bangladesh”, J. Org. Management, Vol. 1(1), pp. 14-21

Baskin, J. (2006). „Corporate Responsibility in Emerging Markets. Journal of Corporate Citizenship, 24, winter: 29-47.

Belaid, B.B. Anis and M. Kamel, „A study of management perceptions of the impact of corporate social responsibility in emerging economies: The case study of Dubai. Journal of Business Ethics: pp: 1-20, 2008.

Berrone , J. Surroca, and J.A. Tribo. „Corporate ethical identity as a determinant of firm performance: A test of the mediating role of stakeholder satisfaction ${ }^{\mathrm{e}}$. Journal of Business Ethics vol. 76, no.2: pp: 130-53, 2007.

Buchholz, „The Natural environment; does it count? "Academy of management Executive. Vol. 18; no.2: pp: 130-133, 2004.

Carlsson, and R. Akerstom, „Corporate social responsibility-a case study of Ohrings Price water house Coopers ${ }^{\mathrm{ce}}$. Unpublished bachelor ${ }^{\text {ee }} \mathrm{s}$ thesis, Lulea University of Technology, 2008.

Carrol, A. B. (2007). Corporate Social Responsibility: Evolution of a Definitional Construct_Business
Society, 38, pp. 268-295.

Carroll, A. B. (1979).A Three-Dimensional Conceptual Model of Corporate Performance. Academy of Management Review, 4, pp. 497-505.

Carroll, A. B. (1991). The Pyramid of Corporate Social Responsibility: Toward the Moral Management of Organizational Stakeholders. Business Horizons, 34, pp. 3948.

Carroll, A., \&Shabana, K. (2010). The business case for corporate social responsibility: A review of concepts, research and practice. International Journal of Management Reviews, 12(1), 85-105. http://dx.doi.org/10.1111/j.14682370.2009.00275.x

Cornelissen (2008), Analysing the importance of stakeholder management. Journal of Corporate Citizenship.

Cornelius, J. Wallance, and R. Tassabehji, „An analysis of Corporate Social Responsibility, corporate identity, and Ethics teaching in business schools ${ }^{\text {ee }} \quad$ Journal of Business Ethics, vol. 76, no.1 pp: 117- 135, 2007.

Crisóstomo, V. L., Freire, F., S., \& de Vascincellos, F. C. (2011). Corporate Social Responsibility, Firm Value and Financial Performance in Brazil. Social Responsibility Journal, 7 (2), 295-309. Curran, M. M., \& Moran, D. (2007).

Davidson W.N.; Worrell, D.L. (1990): "A Comparison and Test of the Use of Accounting and Stock Market Data in Relating Corporate Social Responsibility and Financial Performance” Akron Business and Economic Review 21 (3), 7-19.

Deegan, C. and Rankin, M. 1996, "Do Australian companies report environmental news objectively? An analysis of environmental disclosures by firms prosecuted successfully by the environmental protection agency", Accounting, Auditing and Accountability Journal, Vol. 9, No. 2, pp. 52-69.

Donalson, and L.E. Preston, „The stakeholder theory of the corporation; Concepts, Evidence and Implications ${ }^{\text {ee }}$. Academy of Management Review vol. 20; no.1, pp: 65-91, 1995.

Fauzi, H., Rahman,A.A., Hussain, M., Adenan, M., (2009) "Corporate Social Performance in Indonesian State-Owned Companies and Private-Owned Companies" in Sigh (ed), Handbook of Corporate Performance in Emerging Market. Singapore

Fauzi, Identifying and analyzing the level of Practices of Company"s Social Responsibility in Improving Financial Performance ${ }^{e e}$ Journal of Business and Management, vol. 4; no.2; pp: 109-124, 2004. [9] R.E.

Freeman, „Strategic Management: A stakeholder Approache. Boston: Pitman, 1984.

Freeman, R. E. \& Reed, D. L. (1983). Stockholders and stakeholders: A new perspective on corporate governance. California Management Review, 25(3), 93-94. 
Dr. David A. O. Aunga et al / The Impact of Corporate Social Responsibility on Corporate Financial Perfomance in Tanganyika Wilderness Camps Limited in Arusha Region, Tanzania

Freeman, R. E. (1984). Strategic Management. A Stakeholder Approach. Marschfield, MA: Pitman.

Freeman, R. E. (1994). The Politics of Stakeholder Theory: Some Future Directions. Business Ethics Quarterly, 4 (4), 409-421.

Friedman M., „The social responsibility of business is to increase its profits, In New York Times, New York, pp: 32- 33; 1970.

Friedman, M. (1970). The Social Responsibility of Business is to increase profits. New York Times, 13th September, pp. 122-126.

Gathungu, J. M. \&Ratemo, N. Z. (2013). An Assessment of the Impact of Corporate Social Responsibility on the Strategic Intent at Standard Chartered Bank Kenya Limited. International Journal of Education and Research, 1(5) 1-16.

Gray, D. Owen and C. Adams, „Accounting and Accountability ${ }^{c e}$, Prentice Hall Europe, Great Britain 1996.

Griffin and J.F. Mahon, J.F, „The Corporate Social Performance and Corporate Financial Performance Debate: Twenty-Five years of Incomparable Research ${ }^{\text {ee }}$. Business and Society vol. 36; no. 1, pp: 5-31, 1997.

Heard, J.E. and Bolce, W.J. 1981, "The political significance of corporate social reporting in the United States of America", Accounting, Organizations and Society, Vol. 6, No. 3, pp. 247-254.

Jones M., „Instrumental Stakeholder theory: A synthesis of ethics and economics ${ }^{\mathrm{ee}}$. Academy of Management Review, 20: $404-437,1995$.

Krishnaswami, O. R., \&Satyaprasad, B. G. (2010). Business Research Methods. Mumbai, IND: Global Media.

Kummar M , and G. Udayasuriyan, „The relationship between work-life balance and the perception of quality work life of employees in the electronic industry in Chennai and Bangalore (India) ${ }^{\mathrm{ee}}$. Journal of Business Research, vol. 2; no.1, 2, pp: 33-42, 2008

Lichtenstein, D.R., Drumwright, M.E., and Braig, B.M. (2004). The effect of corporate social responsibility on customer donations to corporate-supported nonprofits. Journal of Marketing, 68(4), 16-32.

Lindgreen, A., Swaen, V., and Johnston, W.J. (2009). Corporate social responsibility: An empirical investigation of U.S. organizations. Journal of Business Ethics, 85(Supplement 2), 303-323.

Louche C., Idowu, S O. and W L Filho. Innovative Corporate Social Responsibility: From risk management to value creation. Edited book. Greenleaf Publishing. London. 2010

Maignan, and O.C. Ferrel, „Corporate social responsibility and marketing: An integrative framework". Journal of the Academy of marketing science, 32(1):3-19,
Mallen Baker (2004), Corporate social responsibility what does it mean?

Manakkalathil J, Rudolf E., 1995. Corporate Social Responsibility in a Globalizing Market.SAM Advanced Mangement Journal,47 (Winter),29-32.

Margarita, Corporate social responsibility and financial performance: Applied financial project ${ }^{\mathrm{e}}$. Haas school of business of University of California, Berkeley, California, 2004

Margolis and J. Walsh, „People and profit? The search for a link between company"s social and financial performance Mahwah, New Jersey. 2001

Mele, D.: 2002, Not only Stakeholder Interests. The Firm Oriented toward the Common Good (University of Notre Dame Press, Notre Dame).

Miles, M. B. and Huberman, A. M. (1994). Qualitative data analysis: An expanded sourcebook, 2nd Ed. Thousand Oaks: Sage.

Mohr, D.J. Webb, and K.E. Harris, „Do customers expect companies to be socially responsible? The impact of corporate social responsibility on buying behaviour". Journal of consumer. Affiliation, vol. 35, pp: 45-72, 2001.

Okiro, K., Omoro, N. \&Kinyua, H. (2013). Investment in Corporate Social Responsibility and Sustained Growth in Commercial Banks in Kenya. Journal of Emerging Issues in Economics, Finance and Banking. An Online International Monthly Journal,3(2), 1057-1064.

S.O. Idowu, C. Louche (eds.), Theory and Practice of Corporate Social $23 \quad$ Responsibility, DOI 10.1007/978 -3-642-16461-3_2, C Springer-Verlag Berlin Heidelberg 2011

Sweeney, L.: A Study of Current Practice of Corporate Social Responsibility (CSR) and an Examination of the Relationship Between CSR and Financial Performance Using Structural Equation Modelling (SEM). Doctoral Thesis. Dublin, Dublin Institute of Technology, 2009.

V.L. Mote, P. Sammuel, and G.S. Gupta, Managerial economics: concepts and cases. Tata McGraw - Hill publishing company, New Delhi, 2008.

Waddock S. A., Graves S. B., 1997, “The Corporate Social Performance-Financial Performance Link", Paper presented at the national meetings of the Academy of Management, Dallas, TX.

Yang, F. J., Lin, C. W., \& Chang, Y. N. (2010). The linkage between corporate social performance and corporate financial performance. African Journal of Business Management, 4(4), 406-41 